\title{
Groundwater modeling of the withdrawal sustainability of Cannara artesian aquifer (Umbria, Italy)
}

\section{Modellazione delle acque sotterranee e prelievo sostenibile dall'acquifero artesiano di Cannara (Umbria)}

\author{
Giovanni Pietro Beretta, Monica Avanzini, Tomaso Marangoni, Marino Burini, Giacomo Schirò, Jacopo Terrenghi, Gaetano Vacca
}

\begin{abstract}
Riassunto: L'acquifero di Cannara (Umbria, Italia) è noto da oltre un secolo ed è uno dei principali punti di approvvigionamento di acqua potabile nella Regione Umbria. All'inizio veniva utilizzato per scopi irrigui, poiché quest'area era prevalentemente agricola fino agli anni 60. Le acque sotterranee, sfruttate da Umbra Acque S.p.A. (Società che fornisce l'acqua potabile), sono a $150 \mathrm{~m}$ al di sotto il livello del suolo e sono contenute in un acquifero poroso confinato, che in origine aveva caratteristiche artesiane. Lo sfruttamento di $200-300 \mathrm{l} / \mathrm{s}$ con nove pozzi ha causato una riduzione del livello piezometrico, mantenendo le condizioni di acquifero confinato, ad eccezione di un periodo molto breve durante il quale la falda è stata depressurizzata in seguito alla siccità e per l'aumento dei prelievi di emergenza in sostituzione di altri rifornimenti idrici potabili (da sorgenti). La presenza occasionale di ioni ferro e ammonio conferma il confinamento delle acque sotterranee la loro facies idrochimica in un ambiente redox, mentre nelle aree vicine e negli acquiferi superficiali si registrano contaminanti antropogenici (nitrati e solventi clorurati). Per la protezione di queste acque sotterranee di interesse strategico (il più importante campo pozzi in Umbria), sono stati rivisti tutti i dati idrologici e idrochimici disponibili e studiata la ricarica dell'acquifero. Le aliquote di prelievi idrici sostenibili e le aree di salvaguardia delle acque sotterranee sono state identificate utilizzando un modello numerico di flusso. Sono state proposte ulteriori azioni per monitorare le acque sotterranee negli acquiferi superficiale e artesiano, insieme ad una sistemazione dei pozzi esistenti.
\end{abstract}

Keywords: : artesian aquifer, well field, sustainability withdrawal, groundwater protection zones, static and dynamic wellhead protection.

Parole chiave: acquifero artesiano, campo pozzi, prelievo sostenibile, aree di salvaguardia, protezione statica e dinamica.

Giovanni Pietro BERETTA 奉:

Università degli Studi di Milano,

Dipartimento di Scienze della Terra “Ardito Desio", Milano

email: giovanni.beretta@unimi.it

Monica AVANZINI

Tomaso MARANGONI

EG Engineering Geology

Marino BURINI

Giacomo SCHIRÒ

Umbra Acque S.p.A

\section{Jacopo TERRENGHI \\ Gaetano VACCA \\ Geologist}

Ricevuto/Received: 09 September 2018-Accettato/Accepted: 20 September 2018 Pubblicato online /Published online: 27 September 2018

This is an open access article under the CC BY-NC-ND license: http://creativecommons.org/licenses/by-nc-nd/4.0/

(C) Associazione Acque Sotterranee 2018

\begin{abstract}
The Cannara aquifer (Umbria, Italy) has been known for more than a century, and is one of the main drinking water supplies in the Umbria Region. In the beginning it was used for irrigation purposes, since this area was mainly agricultural up to the 1960s. The groundwater-exploited by Umbra Acque S.p.A. (a Company supplying drinking water) — is 150 m under ground level and is contained in a porous confined aquifer, which originally had artesian characteristics. Exploitation of 200-300 l/s with nine wells caused a reduction of piezometric level, maintaining the confined aquifer conditions, except for a very short period during which the aquifer was depressurised by drought, and for increase of emergency withdrawals replacing other water supplies (from springs) for drinking purposes. The occasional presence of iron and ammonium ions confirms the confinement of the groundwater and their hydrochemical facies in a redox environment, while in nearby areas and shallow aquifers anthropogenic contaminants (nitrates and chlorinated solvents) are reported. For the protection of this aquifer of strategic interest (the most important well field in Umbria), all hydrological and hydrochemical data available have been reviewed, and the aquifer recharge studied. Sustainable rates of withdrawal, and groundwater protection areas have been identified using a numerical flow model. Further action for monitoring groundwater of both shallow and artesian aquifers, together with well-revamping, have been proposed.
\end{abstract}

\section{Introduction}

The Valle Umbra (VU) is located in central Italy (Fig. 1); since the early 1970s, in the northern part of the VU, defined as Valle Umbria North (VUN), it has been identified as a strategic area for drinking water supply for the Umbria Region and, starting from the '70s, has been widely studied in order to define the potential and quality of the groundwater resource. For many years, geological surveys have covered the whole alluvial valley (Ge.MI.NA., 1962, RPA Risorse Ambientali, 1984, Aquater, 1986), supplemented later by detailed studies focused on specific sectors that wide-ranging studies have indicated as the most significant from a hydrogeological point of view (Marchetti G. and Martini A. 1990 and 1991; Giaquinto S. and Martinelli A. 1991; Giaquinto S. et al. 1991).

A very early study was conducted by Preziotti A. in 1908: it outlined the hydraulic and hydrochemical characteristics of groundwater and reported data regarding the flow rates of rivers. This study proves that the area had been used for water supply since the beginning of the 19th Century, with more than 100 wells most of which for irrigation use, including some artesian wells rising piezometric level above gruound surface. This led to groundwater emergencies characterized by a particular chemical composition of waters (ferrous and sulphurous). Relevant are the measures of flow rate of Topino river and some other tributaries, too : in these years the Topino river had a flow rate of $2.45 \mathrm{~m}^{3} / \mathrm{s}$ in the final section of its valley. 
The first and main reference stratigraphic data came from 15 boreholes, made in the alluvial sediments, that reach depths of 150-200 m, in addition to stratigraphic information on the fluvial-lacustrine deposits which came from the drillings of GE.MI.NA, 1962.

Further data were provided by geoelectrical prospectingabout 500 VES (vertical electrical surveys) — that were subject to multiple processing and reconstruction of the geometry of aquifer bodies placed at different depths (RPA-Risorse Ambientali, 1984).

In all of these studies, several pumping tests were carried out in the Cannara field and in surrounding areas, before the withdrawal of drinking water started in 1986.

Hydrogeological investigations with piezometric measures have been carried out since the early 1970s in the northern sector of the VUN; after which investigations were extended to the southern sector of the VUN. The total number of wells monitored for piezometric level by Regione Umbria and local environmental Agency (ARPA) is around 400 in the whole valley.

In 1985, within the definition of a first groundwater flow model (Aquater 1986), quantitative and qualitative monitoring of groundwater in the Valle Umbra started, encompassing 54 wells (selected from the 400 surveyed) and 16 river cross sections.

In the period 1985-1989, in this control pattern, 12 different water samplings were performed to evaluate several water and groundwater physical-chemical parameters.
In 1987 , to define the aquifer vulnerability in the northern Valle Umbra (Marchetti G. and Martini A., 1990), two piezometric campaigns to determine salinity were performed on about 200 wells; later in this area, detailed studies involved the aquifers near Petrignano, Assisi, and the Cannara territory, where monthly monitoring has been carried out on a set of 30 wells since 1990 .

More detailed studies were conducted in 1989-1990 in the Valle Umbra South (VUS), in order to evaluate the aquifer vulnerability, using piezometric measurements and samples from about 250 wells (Marchetti G. and Martini A., 1991).

The main goal of the research in the VUN and VUS sectors of Umbria Valley was to define situations of incompatibility of the present situation of soil use and start procedures aimed to minimize effects of pollution in progress and the risk of future contaminations, to provide indications about the preferential localization of urban concentrations and productive activities, to design and manage a groundwater monitoring system.

This historical database, the results of the monitoring network, additional measurements, and tests on the rivers and groundwater, aimed to define quantitative and qualitative protection of this important water resource, thus keeping the hydraulic conditions of the confined aquifer during pumping, and maintaining quality, since traces of contaminants (nitrates and chlorinated solvents) are present.

With this purpose, a groundwater flow model was implemented to find the optimal rate of water withdrawals, set wellhead protection areas, and the monitoring network for water wells.

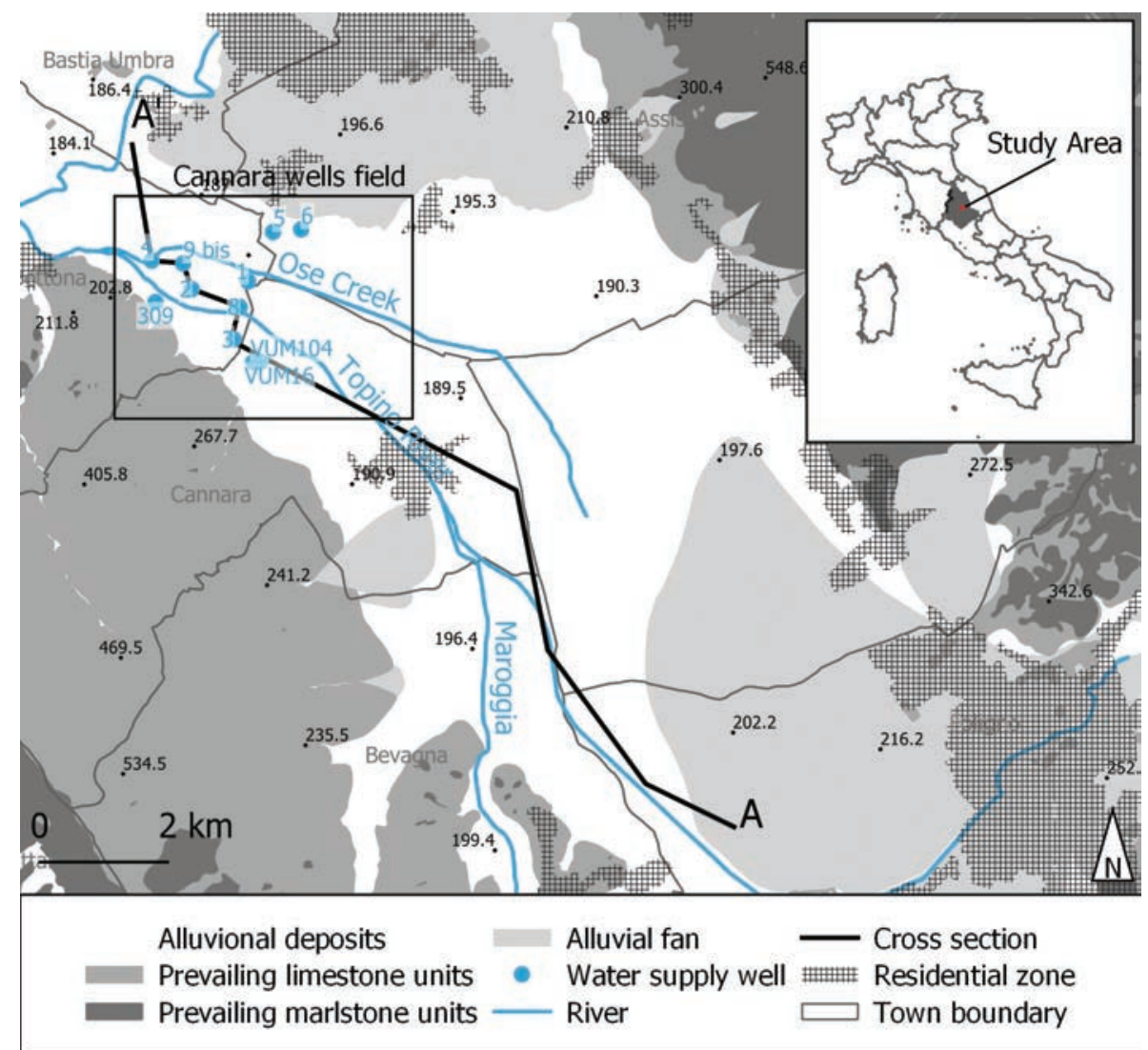

Fig. 1 - Location of Valle Umbra and Cannara wells field in Umbria Region (Italy).

Fig. 1 - Ubicazione della Valle Umbra e del campo pozzi di Cannara nella Regione dell'Umbria (Italia). 


\section{Materials and methods}

The first step of the study required a detailed reconstruction of the conceptual model, developing new and old data of the area of VUN in which the Cannara wells field stands.

A more detailed knowledge has been set in the area occupied by the Cannara confined aquifer, with the aim of assessing the best sustainable use and protection of groundwater.

\section{Geology and hydrogeology of the northern Valle Umbria}

The VU is located among the Monti Martani mountains and the eastern massifs of Monte Subasio-Monti di Foligno and Spoleto, and extends for about $330 \mathrm{~km}^{2}$.

The main rivers in the VUN area, that reaches an extension of about $180 \mathrm{~km}^{2}$ in the territory of the plain, are the Maroggia River in the south, the Topino River in the central portion, and the Chiascio River in the North.

The eastern VUN portion is made up mainly of Mesozoic carbonate formations of the Umbria-Marche series, changing to the west to alluvial deposits with interposition of thick blankets of debris (AA.VV. 1991, Boscherini A. et al. 2005, Regione Umbria, 2007).

Cenozoic flysch units outcrop along the eastern and western boundaries of the VUN, forming the bed of the alluvial and lacustrine deposits.

Alluvial deposits (Pleistocene-Holocene), which characterize the surficial units of the entire valley, are made up of mostly sandy-gravel materials, locally topped by thick and extensive clay deposits, as in the Cannara and Foligno areas. The alluvial complex is more than $150 \mathrm{~m}$ thick in areas of alluvial fans of the River Chiascio, Topino, and Maroggia.

The bed of alluvial units is generally formed by fluvial and lacustrine deposits, and marine deposits (Plio-Pleistocene) of clays and silty clays.

Alluvial deposits appear to be highly permeable, since they are composed mainly of sand and gravel and usually host free groundwater aquifers and, locally, aquifers under pressure (like
Cannara). Transmissivity values of these deposits, obtained through the revision of former tests and the execution of new pumping tests, average between $10^{-3}-10^{-2} \mathrm{~m}^{2} / \mathrm{s}$, with a maximum of $6 \cdot 10^{-2} \mathrm{~m}^{2} / \mathrm{s}$.

Along the eastern side of the valley a complex of detrital deposits (Pleistocene-Holocene) consisting of gravels and sands of continental origin.

Travertine deposits (Pleistocene-Holocene) outcrop locally along both sides of the valley, thus testifying to the rise of waters with high carbon dioxide content along tectonic extensional alignments (Pliocene-Quaternary); these deposits are permeable both for porosity and for fracturing, with transmissivity up to a maximum of $10^{-3} \mathrm{~m}^{2} / \mathrm{s}$.

\section{The Cannara confined aquifer}

Reconstruction of geological cross sections (i.e. Fig. 2) and maps using several stratigraphic data allows the identification of the 3D geometry of two aquifers (shallow and deep) in the Cannara field, having an area of about $40 \mathrm{~km}^{2}$ and terrestrial elevation among 180-190 m a.s.l. ; all data were processed using geostatistical methods.

The shallow aquifer is contained within coarse horizons (gravel and sand), placed into the surface layer of a silty-claysandy nature, at a depth of 9-12 m below ground level. The shallow aquifer system (unconfined or semi-confined) reaches greater depths in the central sector of the VUN and in the upstream sector of Foligno, where it can reach depths of more than $30 \mathrm{~m}$.

The base of the shallow aquifer system has been identified in the alluvial portion of the first significant silty-clay horizon, found at a depth of about 5 to $38 \mathrm{~m}$ below ground level.

Rainfall and smaller streams and watercourses provide recharge of the shallow aquifer.

Hydrometric and surface water flow measurements were carried out to highlight variations due to interference with groundwaters of the shallow aquifer. The hydrometric

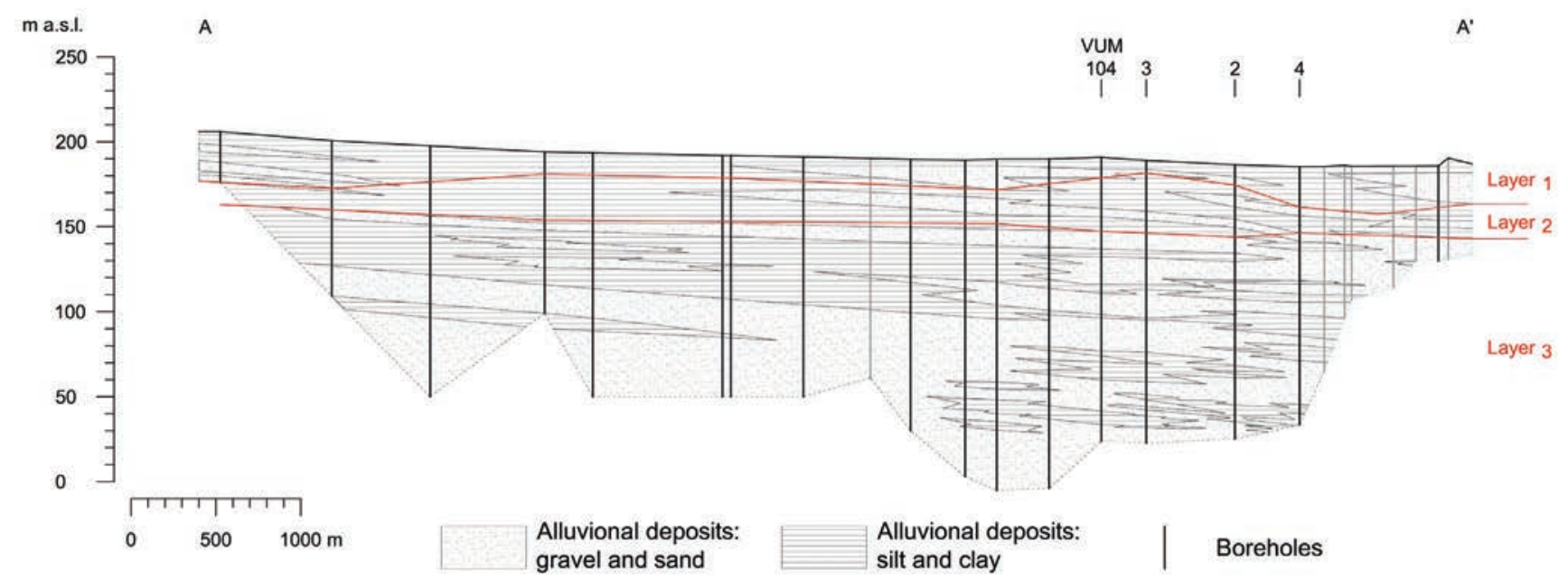

Fig. 2 - Geological cross-section along the Cannara well field and layers in conceptual model.

Fig. 2 - Sezione geologica lungo il campo pozzi di Cannara e livelli del modello concettuale. 
sections measured during two tests performed in year 2011 were: n.5 into Topino river, n.1 into Attone river, n.1 into Molino channel, n.1 into Chiona di Spello channel (tributaries of Topino river) and n.3 into Ose river. It resulted that these watercourses have different behaviors since in some sectors they drain while in other ones they recharge the shallow groundwater.

The thickness of the silty-clay horizon (aquitard or aquiclude) between the shallow and deep aquifer, useful for the evaluation of possible flow rates of exchange (by leakage) between the two aquifers in the subsoil, reaches an average thickness of about $29 \mathrm{~m}$, and a maximum of about $87 \mathrm{~m}$.

The thickness trend is quite uneven, with increasing thickness towards the north-central sector of the valley, on the right bank along the course of the Topino River, especially near the well field.

At depths of 30-40 m, some permeable horizons of the deep aquifer (both confined and artesian) reach the clay substrate (Plio-Pleistocene age), found at even higher depths in the median part of the valley and reaching a maximum of $194 \mathrm{~m}$ below ground level.

The Cannara alluvial aquifer is a permeable elongated body roughly parallel to the Topino River, with a rather high average thickness of sediments $(100 \mathrm{~m})$, which quickly tapers toward the boundaries of the valley.

For reconstruction of the base of the aquifer, stratigraphic data have been integrated with the results of the geoelectrical surveys.

The structural base of the confined Cannara aquifer deepens because the sides towards the middle sector of the Topino River valley are more marked on the left side than on the right side.

The depth ranges between a minimum of about 0 to 10 $\mathrm{m}$ a.s.l. in the central sector stretched to the river, and a maximum of 200 to $220 \mathrm{~m}$ a.s.l. near the lateral boundaries where the base outcrops and corresponds with the ground level. At the Cannara well field, the base of the deep aquifer system is at approximately 20-55 m a.s.l. (130-165 m below ground level).

The recharge area of the Cannara confined aquifer is into the alluvional fan deposits located in the sector where the Topino river enters into the VUN (Fig. 1). The groundwater flow is limited towards the North-West sector near the Chiascio river because there is a gradual reduction of aquifer thickness due to the progressive approach of the impermeable substrate to the topographic surface. Into the VUN area there is not recharge of the confined aquifer by surface watercourses. Only in the area North of Cannara aquifer there are semipermeable deposits that can allow exchange between shallow and deep aquifers.

Several pumping tests (11) in the Cannara wells were performed to characterise hydrogeological parameters, and data about the specific capacity of many other wells were also processed.

The transmissivity values obtained were generally higher than $10^{-2} \mathrm{~m}^{2} / \mathrm{s}$, and only lower in a few cases; hydraulic conductivity was in the range of $10^{-4}-10^{-3} \mathrm{~m} / \mathrm{s}$ and storage coefficient of $3.6 \cdot 10^{-4}-4.2 \cdot 10^{3}$.

The highest values of the hydrogeological parameters of confined aquifer are found in the area between Monti Martani and Topino river, before its confluence into the Chiascio river.

In the piezometric map (Fig. 3) it can be observed that, upstream of the confined aquifer system, piezometric levels are substantially unchanged compared to previous years at approximately $196 \mathrm{~m}$ a.s.l., while towards the Cannara well field there is a marked piezometric depression sat near wells n.3 and n.ex 1, with minimum piezometric levels of less than $168 \mathrm{~m}$ a.s.l. (Fig. 4). This is due to an increase in withdrawals from the Cannara confined aquifer that grew from 117 l/s (in year 1989 due to irrigation wells) to values above $380 \mathrm{l} / \mathrm{s}$ after activation of all drinking wells of Cannara field (average flow rate ranging from 140 to $270 \mathrm{l} / \mathrm{s}$ in the period 1989-2011).

An analysis of the piezometric level registered at the same time in the shallow aquifer reveals that the hydraulic head within the shallow aquifer is generally higher (up to 12-24 $\mathrm{m}$ ) than that in the confined aquifer, pumped by the Cannara wells), except for in the south-eastern area where the difference is less than one meter.

An example of piezometric level fluctuation recorded in a shallow (VUM16) and a deep well (VUM 104) located inside Cannara wells field is shown in Fig. 5.

A large part of the groundwater is of the bicarbonatealkaline earthly kind, thus showing that the main geochemical process is the dissolution of carbonate rocks. There is an alkaline enrichment trend (in particular sodium, sulphates, and chlorides), clearly evident in the confined aquifer of Cannara, due to ion exchange processes in the clay matrix of the aquifer system.

With very few exceptions, the Eh-pH diagrams show that samples from alluvial aquifers range from absolute neutral conditions to light solutions (neutral or slightly alkaline). The samples with the most reducing conditions belong mainly to the confined Cannara aquifer and south Valle Umbra.

Land is predominantly for agriculture, with intensive use of fertilizers and pesticides, while urban settling and industrial activities are scattered throughout the territory.

The monitoring network reports an increase of nitrates in high concentrations in the shallow aquifer, particularly in sectors that are the recharge area of the confined aquifer system of Cannara, which is a worrying fact (ARPA Umbria 2010a).

According to a piece of ARPA research (ARPA Umbria 2010b) the presence of chlorinated solvents (Tetrachloroethylene) is due to various sources of contamination, mainly along the eastern edge of the valley where potential sources of groundwater pollution have long since been present.

\section{Groundwater flow model of the Cannara wall field}

Since the 1990s, two different groundwater flow models of the Valle Umbra have been implemented (Aquater-RPA 1996, and Falcone M. et al. 1991).

Recently, a new and updated groundwater flow model has been developed (EG Engineering Geology 2014) with a study 

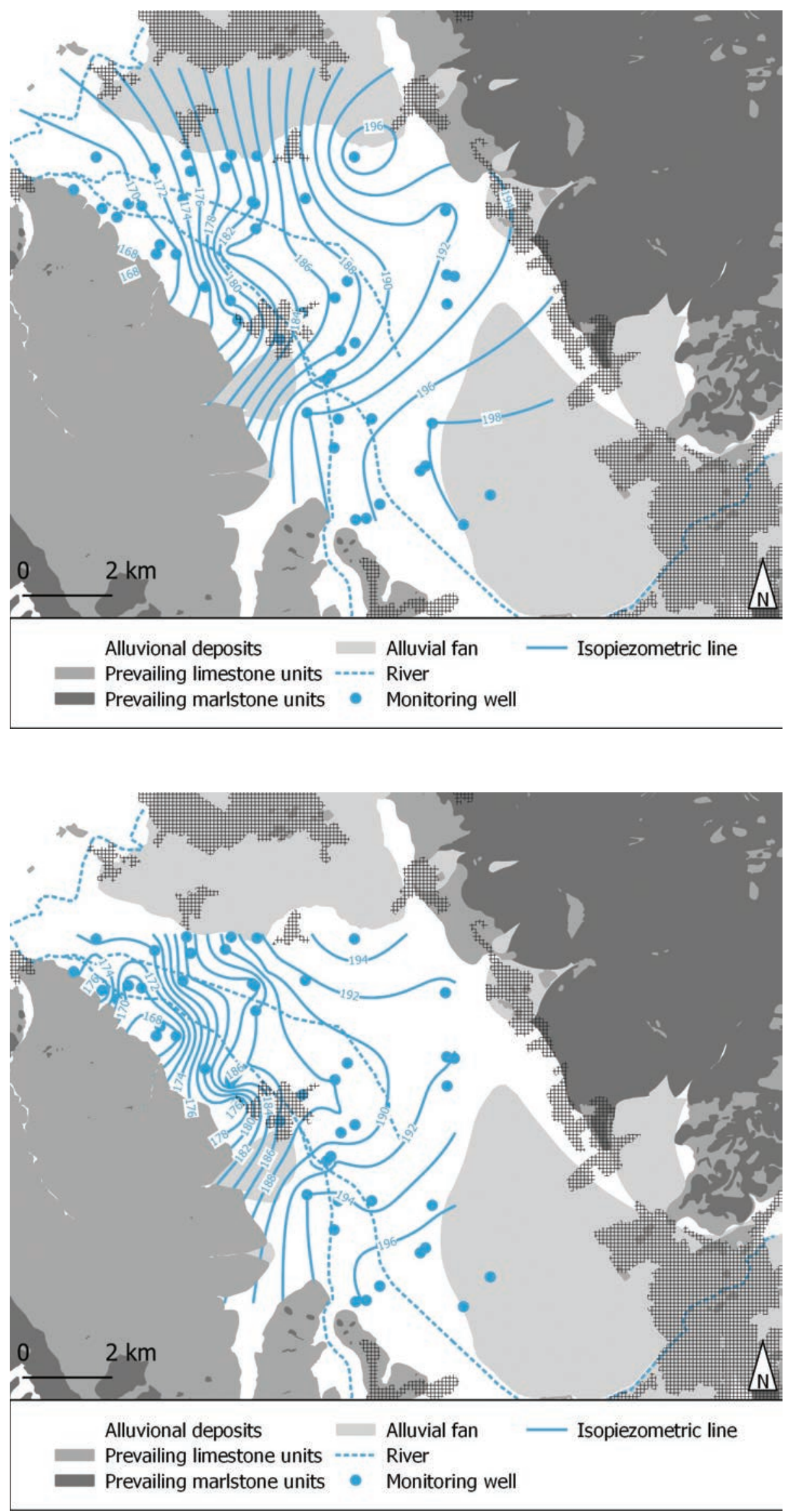

Fig. 3 - Piezometric map ( $m$ a.s.l.) of confined aquifer before pumping from Cannara wells field (May 1989).

Fig. 3 - Carta delle isopiezometriche (m s.l.m.) dell'acquifero confinato antecedente il pompaggio dal campo pozzi di Cannara (maggio 1989).
Fig. 4 - Piezometric map ( $m$ a.s.l.) of confined aquifer after 20 years of pumping from Cannara wells field (May 2011).

Fig. 4 - Carta delle isopiezometriche (m s.l.m.) dell'acquifero confinato dopo 20 anni di pompaggio dal campo pozzi di Cannara (maggio 2011). 


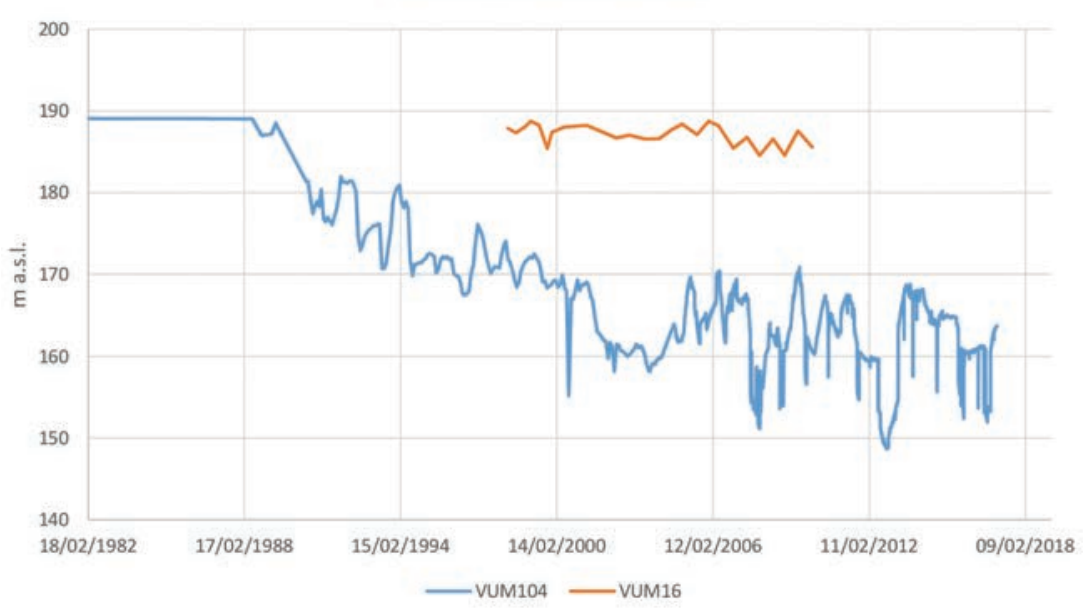

Fig. 5 - Groundwater level fluctuation in shallow aquifer (VUM16) and confined aquifer wells (VUM104).

Fig. 5 - Escursioni del livello piezometrico nei pozzi dell'acquifero superficiale (VUM16) e nell'acquifero confinato (VUM104). of an area of $221 \mathrm{~km}^{2}$ around the municipalities of Bevagna, Cannara, Bettona, Assisi, Spello, and Bastia. This model is based on MODFLOW code (Harbaugh A.W., 2005), and covers a fairly large domain-including the alluvial aquifer of Cannara (Fig. 6 a and Fig. 6 b).

The model was developed according to the standard procedure defined by Anderson M.P. and Woessner W.W. (1992) and ASTM (1995), and uses hydrogeological data previously available from the monitoring networks built since 2000 (ARPA Umbria 2000).

\section{Model design and calibration}

The modelled domain has been divided horizontally using a grid of 260 rows and 340 columns, for a total of 88,400 cells (for each layer) and a size of $50 \times 50 \mathrm{~m}$.

For vertical discretisation, three layers have been defined based on the conceptual model developed using previous data (boreholes, well logs, geophysical prospecting and geological

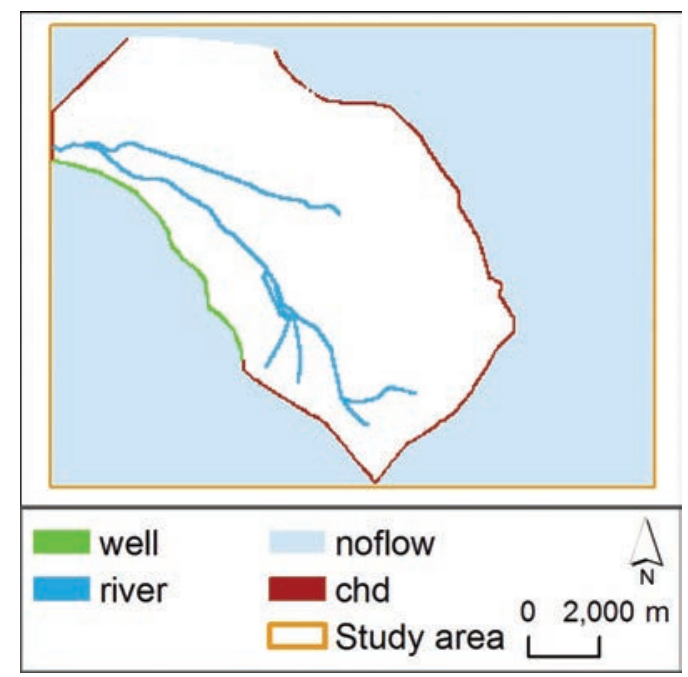

Fig. Ga - Boundary of the groundwater flow model implemented for shallow aquifer (Layer 1).

Fig. 6a - Condizioni al contorno per l'acquifero superficiale (Livello 1) del modello di flusso delle acque sotterranee. cross section):

- Layer 1 - shallow aquifer in connection with surface water, specifically the Marroggia River in the Southern Basin, the alluvial fan of the Topino River, and Ose Creek in the central area; it ranges between $190 \mathrm{~m}$ a.s.l. South and $160 \mathrm{~m}$ a.s.l. NW along the section of closing of the underlying groundwater confined aquifer, near the Chiascio river.

- Layer 2 - low permeability strata (silt-clay) that confines beds between the shallow and deep aquifer system; it has a thickness ranging between 10 at South near the Topino river and a maximum of about $90 \mathrm{~m}$ in correspondence of Cannara wells field, then it reduces again down to values of about $10 \mathrm{~m}$ towards North;

- Layer 3 - confined aquifer in Cannara in the central sector of the valley; the bottom of the aquifer is found at a depth of $180 \mathrm{~m}$ a.s.l. in the southern sector of the aquifer while it rises up to 40-20 m a.s.l. near Cannara wells field

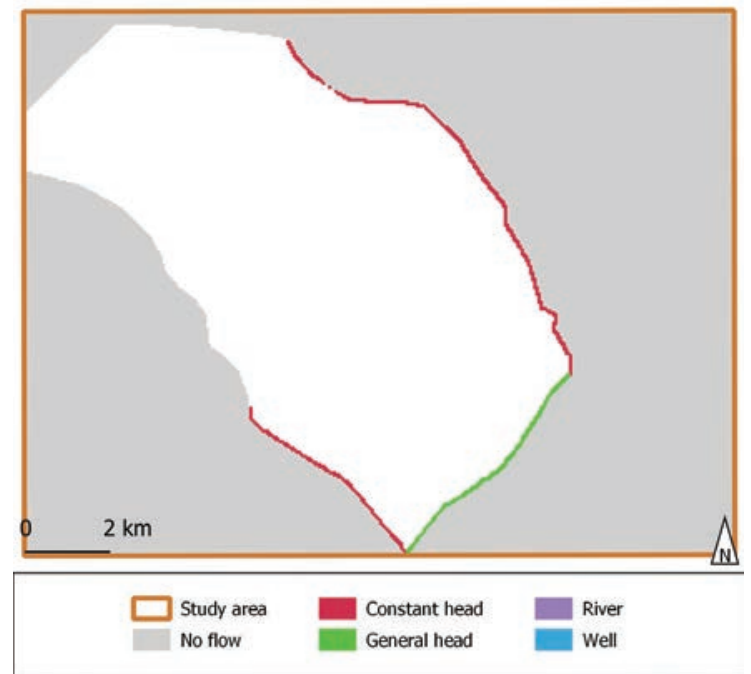

Fig. 6b-Boundary of the groundwater flow model implemented for confined aquifer (Layer 3).

Fig. 6b - Condizioni al contorno per l'acquifero confinato (Livello 3) del modello di flusso delle acque sotterranee. 
and then down again at $140 \mathrm{~m}$ a.s.l. towards the closing section of the aquifer, NW near the Chiascio river. Available data thus reveal that the Cannara confined aquifer is closed toward Northeast.

For boundary conditions, the following were assumed (Fig. 6 a and Fig. 6 b):

- $\quad$ in the upgradient sector of groundwater: General Head Boundary conditions for the shallow and deep aquifer;

- foothill areas - western border of Cannara wells: specified flow rate (into shallow aquifer) and no flow boundary (into deep aquifer);

- foothill areas - east and west body of Bevagna: specified head condition obtained from piezometric maps (shallow and deep aquifer);

- outflow downgradient: boundary conditions like the GHB type for the shallow aquifer, and specified flow rate (no flow) for the deep aquifer since the thickness of the confined aquifer decreases significantly in this sector, falling down near to zero; in fact, historically in the absence of intensive pumping the piezometric level of confined aquifer was above ground level (see also Preziotti A., 1908).

Using data from pumping tests and other well tests, the distribution of the hydraulic conductivity has been mapped using geostatistical methods for the parametrisation of aquifers, aquitards, and aquicludes.

The values used in the modeling area are the following:

- layer 1 (shallow aquifer): hydraulic conductivity values that vary proceeding towards the central area of the modeled domain increasing from $2 \cdot 10^{-5}$ to $5.5 \cdot 10^{-4} \mathrm{~m} / \mathrm{s}$;

- layers 2 (separation aquitard): the values adopted decrease from West and South towards the central part of the modeled domain decreasing from $5 \cdot 10^{-6}$ a $5 \cdot 10^{-8} \mathrm{~m} / \mathrm{s}$;

- layer 3 (confined aquifer): hydraulic conductivity values range between 1.2 and $2 \cdot 10^{-4} \mathrm{~m} / \mathrm{s}$ into the area of Cannara wells field while gradually decrease to value of $3 \cdot 10^{-5} \mathrm{~m} / \mathrm{s}$ moving in the other modeled sectors.

With an average precipitation of about $800 \mathrm{~mm} / \mathrm{year}$ (average annual value calculated at Cannara station for the reference period of the modeling - data from Umbria Region Hydrographic Service), a variable infiltration averaging from 8 to $105 \mathrm{~mm}$ /year was calculated in a steady state, depending on surface lithology and soils of the different sectors of the model. In a transient state the infiltration values vary according to the monthly rainfall always recorded at the Cannara station.

At first processing, calibration in a steady state was set to the hydrologic conditions of May 1989, that is, before the activation of the Cannara wells for drinking water. In that period the withdrawal of existing wells was estimated at $50 \mathrm{l} / \mathrm{s}$. In fact, in the present application the crucial timedependent stress is due to withdrawals in the Cannara well field, with a discharge ranging from 100 to $300 \mathrm{l} / \mathrm{s}$.

Calibration was set using three criteria: 1) comparison between observed and simulated piezometric maps, 2) calculated versus observed head graphs, and 3) statistical parameters, such as ensuring that the ratio between the standard deviation of residuals and the range of piezometric values was kept below 10\%, as stated by Anderson M.P. and Woessner W.W. (1992).

As an example, the statistical parameters obtained during model calibration are shown in Table 1, while the simulated

Tab. 1 - Statistical parameters obtained in calibration phase of the groundwater flow model.

Tab. 1 - Parametri statistici ottenuti nella fase di calibrazione del modello di flusso delle acque sotterranee.

\begin{tabular}{|l|c|}
\hline \multicolumn{2}{|c|}{ Statistical parameters } \\
\hline Residual Mean & 0.426 \\
\hline Abs. Res. Mean & 0.904 \\
\hline Res. Std. Dev. & 1.138 \\
\hline Sum of Squares & 72.402 \\
\hline RMS Error & 1.216 \\
\hline Min. Residual & -2.012 \\
\hline Max. Residual & 3.483 \\
\hline Number of Observations & 49 \\
\hline Range in Observations & 13.81 \\
\hline Scaled Std. Dev. & 0.082 \\
\hline Scaled Abs. Mean & 0.065 \\
\hline Scaled RMS & 0.088 \\
\hline
\end{tabular}

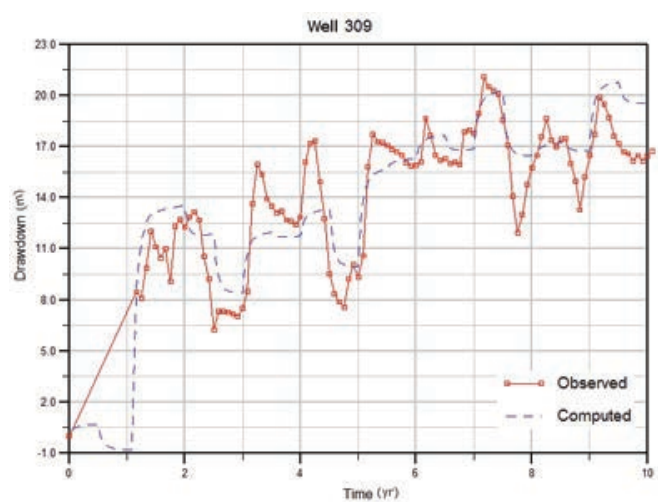

Fig. 7 - Calculated versus observed bydraulic heads in transient simulation at monitoring well n. 309.

Fig. 7 - Carichi idraulici calcolati e misurati nella simulazione in regime transitorio nel pozzo di monitoraggio n. 309.

piezometric map of confined aquifer is drawn in Fig. 7. The sensitivity analysis carried out on the different input parameters used in the model reveals the importance of the hydraulic conductivity of the confined aquifer in determining the piezometric level lowerings, as a result of pumping from Cannara wells field; a possible improvement in the results of the calibration model could be achieved by pursuing further groundwater monitoring and with new stratigrafic informations available in consequence of future drilling to better map the conceptual model of the subsoil.

The water balance obtained in the absence of pumping from Cannara wells field is shown in Table 2. 
Tab. 2 - Water budget (l/s) referred to modelled aquifers (shallow and confined) without withdrawals of Cannara wells freld (model calibration - May 1989).

Tab. 2 - Bilancio idrico (1/s) riferito agli acquiferi modellati (superficiale e confinato) senza i prelievi del campo pozzi di Cannara (calibrazione del modello - maggio 1989)

\begin{tabular}{|c|c|c|c|c|c|c|}
\hline Water budget & Input Layer 1 & Input Layer 3 & Total input & Output Layer 1 & Output Layer 3 & Total output \\
\hline Recharge & 266.37 & - & 266.37 & - & - & \\
\hline Wells in shallow aquifer & - & - & - & 154 & - & 154 \\
\hline Well in confined aquifer & - & - & - & - & 117.5 & 117.5 \\
\hline $\begin{array}{l}\text { Constant Head (upgradient } \\
\text { inflow) }\end{array}$ & 10.89 & 124.7 & 135.59 & 60.5 & - & 60.5 \\
\hline Interaction with surface water & 3.42 & - & 3.42 & 82.5 & - & 82.5 \\
\hline GHB (upgradient inflow) & 3 & 14.2 & 17.2 & 37.4 & - & 37.4 \\
\hline Leakage & 96.6 & 77.3 & 173.9 & 76.5 & 98.7 & 175.2 \\
\hline Lateral groundwater inflow & 30.7 & - & 30.7 & - & - & - \\
\hline TOTAL & 410.9 & 216.2 & 627.1 & 410.9 & 216.2 & 627.1 \\
\hline
\end{tabular}

In a following phase transient simulations were regarded to two periods due to the availability of a different monitoring data set over the years managed by Consorzio Acquedotti Perugia (currently Umbraacque S.p.A.) and ARPA Umbria (Regional Environmental Protection Agency): (1) from May 1989 to April 1999 (Transient period n.1); and (2) from May 1999 to December 2011 (Transient period n.2). The simulation time was divided into stress periods lasting six month each since monitoring of groundwater networks is performed twice in the year: once during irrigated land period (from May to October) and then during non-irrigated land period (from November to April).

During the two transient simulation periods the number of Cannara pumping wells differs.

At the monthly scale, withdrawals for irrigation increase by about 34\% (120 1/s) more than the average (from May to October); this estimated value is related to some specific and punctual data, having no quantification of total withdrawal for irrigation; similarly the value was reduced by $66 \%(75 \mathrm{l} / \mathrm{s})$ considering the other types of groundwater withdrawals, too.

The Topino and Ose rivers were modelled with River Package, with sections discretised into cells with the same surface water behaviour (recharge, drainage, or indifferent) based on hydrometric measures.

The measured-simulated piezometric data in n.11 calibration targets were processed and the calculated versus observed head graphs referred to well n. 309 during the transient simulation is shown for example in Fig. 7.

The graph shows a greater correspondence between simulated and measured piezometric levels during the nonirrigated period, because of the approximate nature of data about pumping water for agricultural use.

During the first period of activation of Cannara wells field the increase of pumping from 156 to 240-250 l/s causes the drying up of the confined aquifer and the change in water budget during the irrigated period of summer 1998 is shown in Table 3. The infiltration term including the recharge for irrigation reaches high values in the shallow aquifer, while the rate of output from the GHB decreases.
Tab. 3 - Water budget (l/s) during summer period - year 1998.

Tab. 3 - Bilancio idrico (1/s) nel periodo estivo - anno 1998.

\begin{tabular}{|l|c|c|}
\hline \multicolumn{1}{|c|}{ Water budget } & Total input & Total output \\
\hline Infiltration & 184.3 & - \\
\hline Wells & 26 & 370.7 \\
\hline Interaction with surface water & 8.6 & 23.4 \\
\hline Constant Head (upgradient inflow) & 151.5 & 62.2 \\
\hline GHB (upgradient inflow) & 16.7 & 0.4 \\
\hline Storage & 79.7 & 10.3 \\
\hline TOTAL & 466.9 & 466.9 \\
\hline
\end{tabular}

On the contrary, during non-irrigated winter period the water balance is changed as shown in Table 4 .

The water storage takes place almost completely into the shallow aquifer while the supply of groundwater to watercourses increases

Tab. 4 - Water budget (l/s) during winter period - year 1994.

Tab. 4 - Bilancio idrico (1/s) nel periodo invernale - anno 1994.

\begin{tabular}{|l|c|c|}
\hline \multicolumn{1}{|c|}{ Water budget } & Total input & Total output \\
\hline Infiltration & 35.7 & 26.4 \\
\hline Wells & 26.0 & 265 \\
\hline Interaction with surface water & 6.7 & 30.7 \\
\hline Constant Head (upgradient inflow) & 156.8 & 58 \\
\hline GHB (upgradient inflow) & 17.9 & 10.6 \\
\hline Storage & 147.7 & 0.1 \\
\hline TOTAL & 390.9 & 390.9 \\
\hline
\end{tabular}

The flow model was implemented with operational goals, trying to produce a first tool for management and protection of an important groundwater resource that could subsequently be improved. This preserving a scientific approach of sequence of work stages, starting from the conceptual model and checking the compliance between experimental and simulated data, with particular reference to piezometric trends in space and time. 
Tab. 5 - Water budget (l/s) referred to modelled aquifers (shallow and confined) - simulation with withdrawals from Cannara wells field of $200 \mathrm{l} / \mathrm{s}$.

Tab. 5 - Bilancio idrico (1/s) riferito agli acquiferi modellati (superficiale e confinato) - simulazione con prelievo di 200 1/s dal campo pozzi di Cannara.

\begin{tabular}{|c|c|c|c|c|c|c|}
\hline Water budget & Input Layer 1 & Input Layer 3 & Total input & Output Layer 1 & Output Layer 3 & Total output \\
\hline Recharge & 266.3 & - & 266.3 & - & - & \\
\hline Wells in shallow aquifer & - & - & & 154 & - & 154 \\
\hline Well in confined aquifer & - & - & - & - & 311 & 311 \\
\hline $\begin{array}{l}\text { Constant Head (upgradient } \\
\text { inflow) }\end{array}$ & 15.5 & 156.1 & 171.6 & 56.7 & - & 56.7 \\
\hline Interaction with surface water & 30.4 & & 30.4 & 8.6 & - & 8.6 \\
\hline GHB (upgradient inflow) & 28.4 & 16.7 & 45.1 & - & - & \\
\hline Leakage & 85.4 & 226.9 & 312.3 & 223 & 88.7 & 311.7 \\
\hline Lateral groundwater inflow & 16.2 & & 16.2 & - & - & \\
\hline TOTAL & 442.2 & 399.7 & 842 & 442.3 & 399.7 & 842 \\
\hline
\end{tabular}

By comparing the results of a large number of detailed simulations of different scenarios, a withdrawal of $200 \mathrm{l} / \mathrm{s}$ considering an average condition for the water budget was selected for the reasons explained below.

A processing produced a simulation carried out by inserting the $200 \mathrm{l} / \mathrm{s}$ from the Cannara public wells (average water withdrawal), obtaining a piezomeric map in Fig. 8 and a water budget reported in Table 5, which emphasizes the establishment of a new balance between input and output flows in the aquifers

The comparison among the data brought in Table 2 and

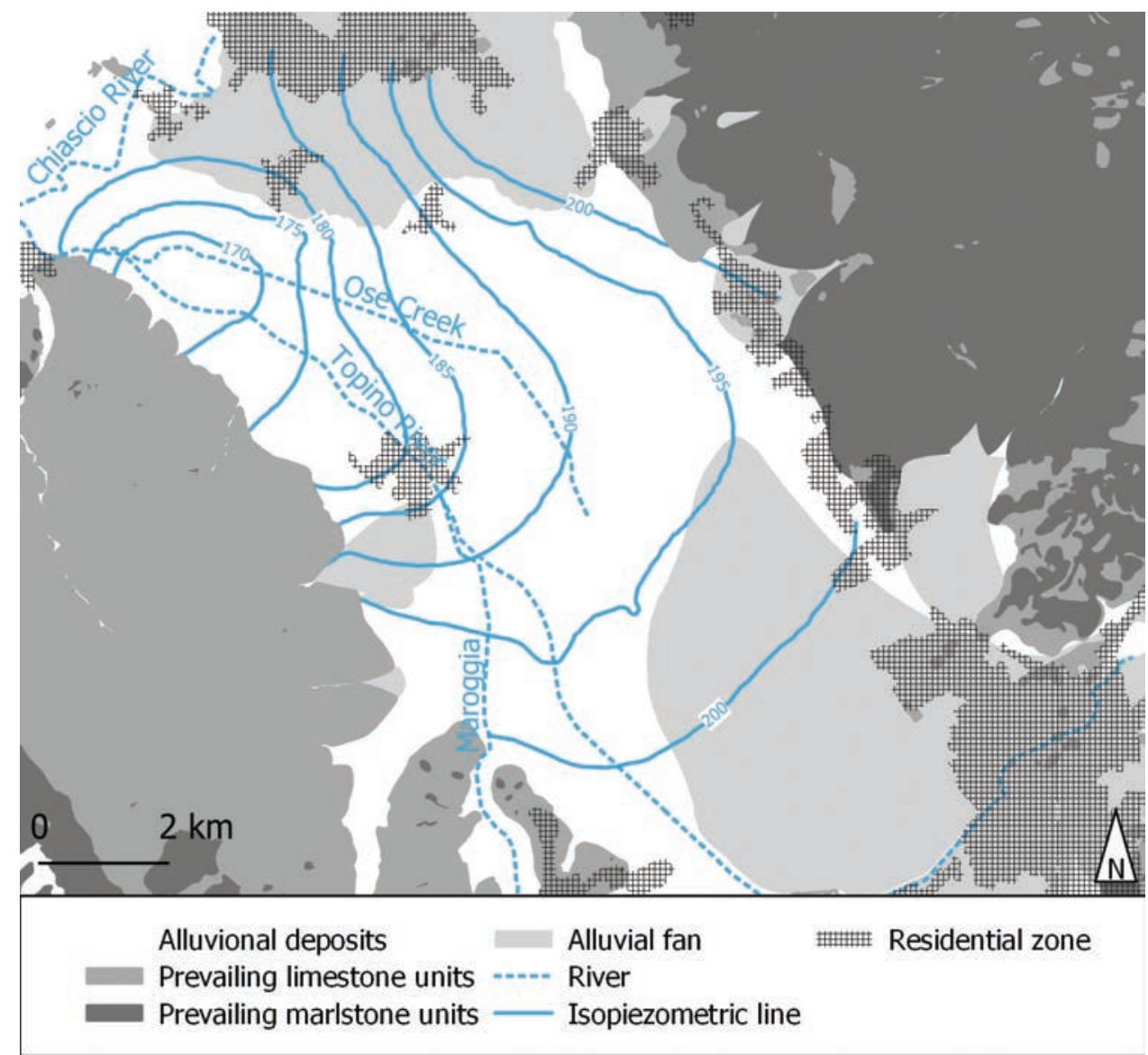

5 allows the following observations about the total values of water budget:

- Constant head: increase of $26.5 \%$ in input terms and reduction in output terms of $6.3 \%$.

- Interaction with surface water: contributions from surface waters into the shallow aquifer increase by an order of magnitude.

- GHB: significant increase of $162 \%$ in input flow terms.

- Leakage: percentage values of increase of input and output terms remain roughly the same $(79 \%)$

- Lateral Groundwater inflow: reduction of input terms of about $90 \%$.

Fig. 8 - Simulated piezometric map ( $m$ a.s.l.) of confined aquifer: withdrawal of $200 \mathrm{l} / \mathrm{s}$ from Cannara wells.

Fig. 8 - Carta delle isopiezometriche simulate (m s.l.m.) dell'acquifero confinato: prelievo di 200 1/s dai pozzi di Cannara. 
In the history of exploitation of Cannara wells, a significant drought forced a major water withdrawal, which caused a significant lowering of the groundwater level.

For this reason, a first sustainable withdrawal strategy was evaluated in order to preserve this important aquifer in the Umbria Region from a quantitative perspective.

By modelling a steady and transient states, an attempt was made to identify the sustainable withdrawal rate from the Cannara wells, pumping from the deep aquifer.

The various simulations implemented (not shown below for aim of simplicity) suggest that even a prolonged withdrawal with a rate of $200 \mathrm{l} / \mathrm{s}$ does not induce noticeable drawdowns in monitoring piezometers, such as:

- increase of leakage effect and inflow of groundwater from the shallow aquifer;

- a partial desaturation of the deep aquifer (passing from confined to partially unconfined).

Both of these situations may cause a reduction in aquifer potential capacity, and a deterioration of groundwater quality.

This average flow rate of $200 \mathrm{l} / \mathrm{s}$ has been deduced not only from the modeling processes carried out, but also from the analysis of the hystorical data of piezometric measurements from the year 1990 .

The piezometric level compared with the average withdrawal rates illustrate the aquifer response to changes in pumping of the Cannara public wells, with excursion of values up to $10 \mathrm{~m}$ passing from 155 to $270 \mathrm{l} / \mathrm{s}$.

This value of withdrawal (corresponding to over 6.3 million $\mathrm{m}^{3} /$ year) must be considered at an annual average rate and then adjusted during the reference period; in fact, higher flow rates may be eligible for short durations, under conditions to be followed by periods with lower flow rates, so as to respect the average annual value.

\section{Use of a groundwater flow model for the protection of wells in the Cannara aquifer}

The implementation of the groundwater flow model had the purpose to outline the wellhead protection areas of Cannara wells field, too.

The relevant government regulations for wellhead protection areas are the "Decreto Legislativo n. 152/2006", the "Accordo Stato-Regioni December 12 ${ }^{\text {th }}, 2002$ ", and the "Delibera della Giunta Regionale Umbra n.1968 December $22^{\text {th }}, 2003^{\prime \prime}$ at local level.

There are areas with prohibitions and regulations for activities and settlements. Starting from the single well, these areas are divided into: absolute protection zone, respect zone (divided into restricted and enlarged), and protection zone, on the basis of geometric or chronologic criteria of delineation.

A geometric criterion is applied for a wellhead absolute protection zone: a fixed radius of $10 \mathrm{~m}$ around the wells. For a wellhead respect zone, the chronological criteria are defined using a "time-of-travel capture zone" of 60 days for a restricted area, and of 365 days for an enlarged one.

Two rules are stated for the respect zone: static protection (constraints on activities and settlements) and dynamic protection (monitoring groundwater inflow and surficial anthropogenic activities), according to guidelines proposed by Beretta G.P. et al. (2003).

For the delineation of wellhead protection areas, the Particle Tracking Method was applied using the numerical code PATH3D (Zheng C. 1988), and for this purpose the output of the flow model, implemented using the code MODFLOW, was interfaced with software which reconstructed the trajectories of particles, and computed the travel time.

Wellhead protection areas are designed to operate in two different scenarios for the Cannara well field: A) a pumping rate of $200 \mathrm{l} / \mathrm{s}$ (optimised withdrawal) and B) a pumping rate of $280 \mathrm{l} / \mathrm{s}$ (maximum withdrawal).

In Fig. 9, the time-related capture zone boundaries for 60 and 365 days in scenario $\mathrm{A}$ are shown.

A specific survey was conducted to identify the main facilities and activities that may degrade water and groundwater quality, providing guidance for their accommodation and for the revamping of old wells in the area (for drinking or irrigation water), too.

In respect zones, areas extending to about $0.5 \mathrm{~km} 2$ are identified as grazing and/or livestock housing, land cultivation, areas for production activities, sewer lines and areas without sewer lines, parking, roads, and private wells. Compatibility and risk mitigation measures were assessed for activities and settlements.

For the protection zone (about $3608 \mathrm{ha}$ ) a preliminary area is proposed of approximately $1 \mathrm{~km}$ over the perimeter mapped as the "limit of the confined aquifer system of Cannara" in the regional study (Regione Umbria 2007).

Since 1998, a groundwater monitoring network has been maintained by ARPA Umbria (2000) in the Valle Umbra (as a part of the interregional project, PRISMAS); the network has subsequently been optimised and adopted as a

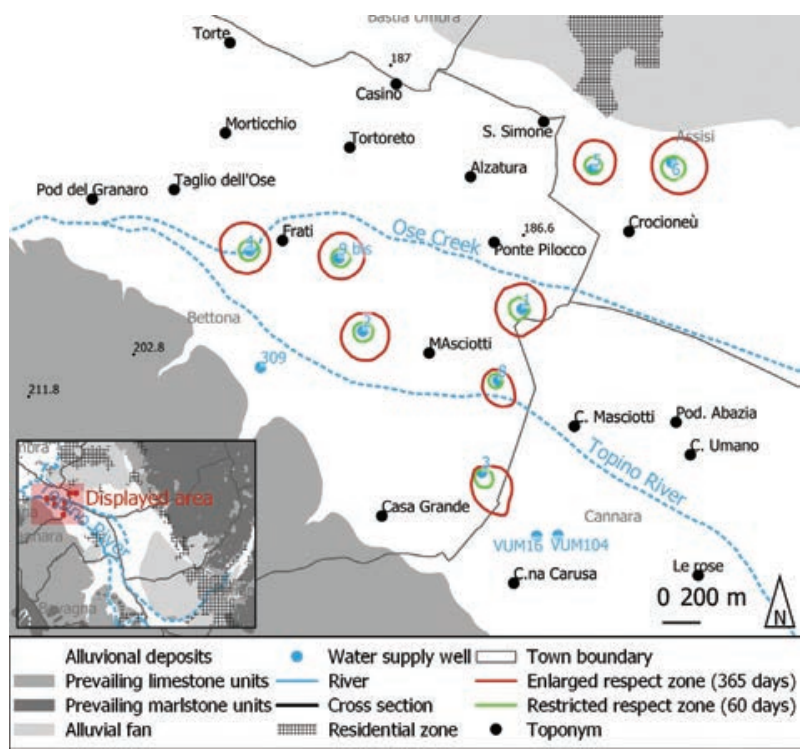

Fig. 9 - Time-related capture zone boundaries referred to 60 and 365 days (Scenario A).

Fig. 9 - Limiti delle isocrone riferite a 60 e 365 giorni (Scenario A). 
regional monitoring network of significant aquifers. In 2011 it was integrated with new checkpoints, while others were abandoned, for the definition of quality objectives requested by a European Directive. An automated monitoring network was instead established between 2001 and 2006.

Presently, for groundwater monitoring of the Cannara aquifer, there are only seven points with periodic measurements, and four points with continuous measurement equipment and automatic readings; none of them tracking the closing section downgradient of the Cannara wells and the eastern boundary of the confined aquifer.

For these reasons, the integration of the existing monitoring proposed network provides:

- n.1 piezometer in the shallow aquifer in the area of the Cannara deep aquifer, to evaluate the different response of the water table and piezometric levels to recharge and well withdrawal;

- n.1 piezometer in the shallow, and one piezometer in the deep aquifer, placed laterally to the main valley to the limit of the aquifers (hilly area);

- n.1 piezometer in the deep aquifer in the closing section downgradient of Cannara well field.

\section{Discussion}

Strategic resources for drinking water supply have a limited distribution within a territory, and therefore their use should be appropriately studied and regulated.

The Protection Plan of Regione Umbria (Regione Umbria 2009) identifies the main categories of water-bound points for human consumption, which must be divided into A) points of strategic importance, B) points of general importance, and C) locally important points. The Cannara wells are type A, being a well field characterised by a reservoir of more than 6000 inhabitants with a withdrawable flow rate greater than $30 \mathrm{l} / \mathrm{s}$, and these groundwaters are not currently substitutable with other supply sources.

Some concepts have been applied to Cannara confined aquifer recognizing the need to ensure an adequate water supply in the short and medium term, while further investigations and insight studies will need to assess the longterm exploitation of groundwater resources at regional and national levels, considering the impact of climate change on groundwater resources, too

The issue of sustainability of groundwater exploitation has been addressed for over a century, passing from "safe yield" (Lee C.H. 1915) to "sustainable yield" in recent years (for example Alley W.M. and Leake S.A. 2004; Bredehoeft 1997 and 2002; Kalf F.R. P., Woolley D.R. 2005; Sophocleous M.A. 2000; U.S. Geological Survey 1999) assuming that knowledge of the water budget is fundamental in choices (U.S. Geological Survey 2007) involving ethical aspects too (Llamas R. 2004).

When new conditions are induced in a hydrogeological basin, such as withdrawals of groundwater from wells, there exist transitional conditions, later evolving towards a pseudo steady state if the withdrawal rate is constant in time.
Activation of withdrawals in the deep aquifer of Cannara in 1989 caused an unavoidable reduction of piezometric levels.

In the ecosystemic approach suggested by RIZA-RIVM (1991), the effects of withdrawals do not alter the base flow of surface waters, wetlands, and flora and fauna that depend on them.

For these reasons, a scenario allowing the preservation of the confined condition of the Cannara aquifer was selected from the model, with a total pumping of $200 \mathrm{l} / \mathrm{s}$ from the wells.

This rate, probably overcome for a limited period only in emergency conditions, does not increase the leakage effect and inflow of groundwater vulnerable to pollution from the shallow aquifer, and does not induce a change in the deep aquifer hydraulic properties, moving out of confined into partially unconfined.

Keeping a sustainable yield and almost constant piezometric levels would also allow the reduction and stabilisation of the subsidence in the area, which is estimated using the SBASDInSAR Technique as $6-8 \mathrm{~cm}$ at the centre of the well field after nearly 12 years of activity (Guzzetti F. et al. 2009).

National and regional rules define the groundwater wellhead protection area to preserve the use of groundwater for drinking.

The solution recommended for confined aquifers is an integrated approach to detect the presence and degree of its confinement (U.S. Environmental Protection Agency 1991), according to the results of a previous study.

A geological approach using reconstructions of geological maps of the surface and geological sections verified the presence of a protective surface horizon, with thickness ranging from 29 to $87 \mathrm{~m}$, able to confine the aquifer. The geometry of the confined aquifer was tracked, with reconstruction of its top and bottom.

In the hydrogeological approach, piezometric maps identify confinement groundwater conditions, previously artesian conditions, with groundwater level about $3 \mathrm{~m}$ above ground level. Values of the storage coefficient calculated from pumping tests are typical of a semiconfined/confined aquifer $\left(10^{-3}-10^{-4} \mathrm{~m} / \mathrm{s}\right)$ and the piezometric depression induced by pumping extends for several kilometres and very quickly due to the high value of hydraulic diffusivity.

In the hydrochemical approach, natural characteristics of the water consist of negative values of Eh and lack of dissolved oxygen in groundwater, thus identifying a redox environment, as well as the mobilisation of iron in solution.

Despite high environmental pressure due to intensive agriculture, nitrate values are generally low (less than 5 $\mathrm{mg} / \mathrm{l})$, while ammonium ions are present. Low $\mu \mathrm{g} / \mathrm{L}$ values of chlorinated solvents in a confined aquifer are traced back to feeding grounds in the eastern side (paleo - alluvial fan of the Topino river), to the partial communication with the overlying unconfined aquifer in a small area, and to well structure (ARPA Umbria 2010a and 2010b 2012).

Distance, drawdown, time of travel, flow boundaries, and assimilative capacity are suggested as criteria for the protection of wells in the confined aquifer. 
Since groundwater inflows from the bodies and from the overlying unconfined aquifer induce the presence of traces of anthropogenic contaminants, the approach based on time of travel has been selected for the Cannara wells, as suggested by the U.S. Environmental Protection Agency (1991), by applying the static and dynamic protection criteria stated by Italian rules.

The complexity and heterogeneity of the subsoil, with a multi-layered structure, required the implementation of a groundwater flow model using the code MODFLOW (Harbaugh A.W., 2005) interfaced with the computing code PATH3D (Zheng C. 1988), to track the pathlines and timerelated capture zone.

Results from modelling allow the identification of some aspects of sustainable use of the Cannara well field, avoiding a change of hydraulic conditions (from a confined to unconfined aquifer) due to groundwater withdrawals.

\section{Conclusion}

In Regione Umbria, the water supply is generally guaranteed by springs in the limestone massifs and from wells in the valley, especially in Valle Umbra and in the valley of the Tiber river.

Springs have a considerable rate, even more than hundreds of $\mathrm{l} / \mathrm{s}$, but they are very vulnerable to climatic drought events and, in the long term, could be affected by climate change; significant rate reductions occurred, for example, in 2003, resulting in a water supply crisis.

For this reason, the flow of groundwater in porous media in the valley is of great importance, and allows the management of emergency situations.

Wells undergo critical situations as they can suffer overexploitation and contamination from anthropogenic sources (urban, industrial, and agricultural), especially in valley areas.

In the northern part of the Valle Umbra, there is the unique and important resource of the Cannara confined aquifer, known for over a century and exploited first for irrigation purposes, and then for drinking water.

The analysis of flow conditions and groundwater withdrawal required a revision of all geological and hydrogeological data previously available, as well as integrative surveys: pumping tests, hydrometric and piezometric measurements, and water analysis.

All data were processed using geostatistical methods, and then used for the implementation of a groundwater flow model (by MODFLOW), mainly aiming to define a first sustainable withdrawal and wellhead protection areas.

The sustainable withdrawal, in quantitative terms, could be defined as the maximum pumping rate that can be maintained indefinitely without affecting the groundwater reservoir, and is different from the concept of natural undisturbed flow, because it assumes the concept of sustainability in a broader sense.

The assessment of the "Sustainable Pumping Rate" for the case was conducted by means of a numerical flow model calibrated both in undisturbed conditions without withdrawals from drinking wells (steady state model of May 1989), and in conditions of exploitation (steady state and transient model).

Modelling of the steady state allowed the checking of the conditions of the initial groundwater balance, while the following transient simulations were run to analyse the specific time of aquifer emptying (high withdrawals and low rainfall) and of the subsequent aquifer recovery (low withdrawals and heavy rains).

The average annual pumping rate of $200 \mathrm{l} / \mathrm{s}$, assumed to be sustainable in the short-medium term, was settled not only by modelling calculations, but also by analysis of experimental data of piezometric measures.

Different calculations performed suggest that even a prolonged withdrawal with this magnitude does not induce a significant fall in levels into monitoring piezometers that may:

- increase the effect of leakage from shallow aquifer, keeping it within an acceptable rate which does not affect the circulating flow rate into the most surficial portion of the aquifer, and into the surface drainage network;

- avoid a partial desaturation of the confined aquifer, which would lead to deterioration in the quality of water resources.

Authorised withdrawal of up to $300 \mathrm{l} / \mathrm{s}$ must cover periods of peak demand for adverse weather events (drought) or other specific emergency situations, but it seems not to be sustainable in the medium term.

It is recommended to implement additional model simulations in order to cover the effects of other forcing factors that may affect water budget terms, such as both the recharge due to meteoric regime modified by the climate change and the use of land due to changes in the structure of agricultural activities and urban settlements over time.

On the qualitative side, wellhead protection areas have been drawn with the travel time method (using PATH3D code), usually suggested for semiconfined-confined aquifers, especially for the respect zone.

Potential point and non-point sources of contamination within the areas have been identified, and remedial solutions have been proposed, according to the "static protection" principles of Italian rules.

The monitoring system has been revised in order to control these areas, adding piezometers in the shallow and deep aquifer in the critical areas, according to the "dynamic protection" principles of Italian rules.

Contaminants may come from recharge areas to the east and from areas where the deep aquifer is semiconfined, to the north; at present, deep waters contain traces of chlorinated solvents. 


\section{REFERENCES}

ALLEY W.M., LEAKE, S.A. (2004) - "The journey from safe yield to sustainability". Ground Water, vol 42, no. 1, p. 12-16.

AQUATER-RPA (1984) - "Studio idrogeologico della Valle Umbra Sud. Regione dell'Umbria" (Hydrogeological study of the Valle Umbra South), rapporto interno.

AQUATER-RPA (1986) - "Modello matematico del sistema acquifero alluvionale della Valle Umbra" (Mathematical model of Valle Umbra alluvial aquifer system). Regione dell'Umbria, rapporto interno.

AA.VV. (1991) - "Le acque sotterranee in Umbria" (The groundwater in Umbria). A cura di S. Giaquinto, G. Marchetti, A. Martinelli, E. Martini, 212 pp., Protagon -GNDCI-CNR (pubbl. 413), Perugia.

AMERICAN SOCIETY FOR TESTING AND MATERIALS (1995) - "Guide for documenting a Ground-Water Flow Model Application". ASTM D5718-95, West Conshohocken, PA

ANDERSON M.P., WOESSNER W.W. (1992) - "Applied groundwater modeling: Simulation of flow and advective transport". $381 \mathrm{pp}$. San Diego, California, Academic Press

ARPA Umbria (2000) - "Progetto Interregionale Sorveglianza e Monitoraggio Acque Sotterranee PRISMAS; Sintesi dei Risultati/Risultati Metodologici" (Inter-regional project of groundwater suveillance and monitoring PRISMAS). Ministero dell'Ambiente, ANPA, Regione Basilicata, Regione Liguria, Regione Piemonte, Regione Umbria. 111 pp. Perugia,

ARPA Umbria (2006) - "Monografia/18 - Bilanci idrogeologici delle principali idrostrutture (acquiferi alluvionali, vulcanici e carbonatici)" (Monograph/18 - Hydrogeological balance of the main hydrostructures (alluvial, volcanic and calcareous) - Allegato a PTA Regione Umbria 2005, Perugia

ARPA Umbria, (2008) - "Il monitoraggio continuo dei livelli di falda in Umbria". (Monitoring recording of the groundwater levels in Umbria). Rapporto interno, Perugia.

ARPA Umbria, (2010a) - "Contaminazione delle acque sotterranee da composti organo alogenati nell'acquifero nei Comuni di Assisi e Bastia Umbra" (Groundwater contamination by organochlorurated compounds in the Assisi and Bastia Umbra Municipality). Rapporto interno, Perugia

ARPA Umbria, (2010b) - "Zone Vulnerabili ai nitrati di origine agricola: valutazione delle tendenze delle concentrazioni dei nitrati" (Nitrates vulnerability zones due of the agricultural origin). Rapporto interno, Perugia

ARPA Umbria (2012) - "Contaminazione delle acque sotterranee da composti organo-alogenati nell'acquifero alluvionale della Valle Umbra a Sud del F. Chiascio" (Groundwater contamination from organoalogenated compounds in the alluvial aquifer of the Valle Umbra to the South od Chiascio River). Rapporto Conclusivo, Dicembre 2012

BERETTA G.P., FARINA M., ZAVATTI A. (2003) - "Aree di salvaguardia delle captazioni idriche - Linee guida" (Guidelines of wellhead protection zones). CNR-Progetto strategico: Ambiente e Territorio, I manuali ARPA, 132 pp. Bologna

BOSCHERINI A., CHECCUCCI R., NATALE G., NATALI N. (2005) - "Carta idrogeologica della Regione Umbria a scala 1:100 000" (Hydrogeological map of the Umbria Region in scale 1:100.000). Giornale di Geologia Applicata 2, 399-404 pp.

BREDEHOEFT J.D. (1997) -"Safe Yield and the Water Budget Myth". Groundwater, Volume 35, Issue 6, November, 929-929 pp.

BREDEHOEFT J.D. (2002) - "The Water Budget Myth Revisited: Why Hydrogeologists Model”. Groundwater, Volume 40, Issue 4, July, 340-345 pp.
CHIODINI G., GIAQUINTO S., MARCHETTI G., MARTINELLI A. (1990) - "Il monitoraggio idrogeologico ed idrochimico del sistema alluvionale della Valle Umbra (Umbria): prima analisi dei risultati" The hydrogeological and hydrochemical monitoring of the alluvial sistem in Valle Umbra (Umbria): first analysis of results). in Atti del $1^{\circ}$ convegno nazionale sulla protezione e gestione delle acque sotterranee: metodologie, tecnologie e obiettivi, vol. 2, pp. Marano sul Panaro (Modena).

CHIODINI G., DEL GIUDICE C., GIAQUINTO S., MARCHETTI G., MARTINELLI A., MARTINI E. (1991) - "Il monitoraggio idrogeologico ed idrochimico del sistema alluvionale della Valle Umbra". in AA.VV., Le acque sotterranee in Umbria, a cura di S. Giaquinto, G. Marchetti, A. Martinelli, E. Martini, Protagon -GNDCI-CNR (pubbl. 413), Perugia, 83-94 pp..

EG ENGINEERING GEOLOGY (2014) - "Studio idrogeologico e costruzione del modello matematico dell'acquifero alluvionale di Torte (Comuni di Bettona e Cannara) finalizzato alla definizione dei limiti di prelievo e all'individuazione delle aree di salvaguardia - Fasi I, II e III" (Hydrogeological study and mathematical model implementation of the Torte alluvial aquifer (Municipality of Bettona and Cannara) aimed to study the withdrawals limits and wellhead protection zones - I, II and III Phases). Studio svolto per Umbra Acque S.p.A., Rapporto interno

FALCONE M., MARCHETTI G., MARTINI E., PIZZI G. (1991) - "Il modello matematico di flusso dell'acquifero alluvionale della Valle Umbra" (Mathematical groundwater flow model of the Valle Umbra alluvial aquifer). Iin AA.VV., Le acque sotterranee in Umbria, a cura di S. Giaquinto, G. Marchetti, A. Martinelli, E. Martini, Protagon -GNDCI-CNR (pubbl. 413), 67-82 pp., Perugia,

GE.MI.NA. (1962) - "Ligniti e torbe dell'Italia continentale". Geomineraria Nazionale, 319 pp., Roma.

GIAQUINTO S., MARTINELLI A. (1991) - "Studi sull'acquifero artesiano di Cannara" (Study on the Cannara artesian aquifer). In AA.VV., Le acque sotterranee in Umbria, a cura di S. Giaquinto, G. Marchetti, A. Martinelli, E. Martini, Protagon -GNDCI-CNR (pubbl. 413), , 145-167 pp.. Perugia

GIAQUINTO S., MARCHETTI G., MARTINELLI A., SANTUCCI A. (1991) - "L'idrochimica dell'acquifero alluvionale della Valle Umbra Sud" (Hydorchemistry of the alluvial aquifer of the Valle Umbra Suoth). In AA.VV., Le acque sotterranee in Umbria, a cura di S. Giaquinto, G. Marchetti, A. Martinelli, E. Martini, Protagon -GNDCI-CNR (pubbl. 413), , 95-108 pp., Perugia

GUZZETTI, F., MANUNTA M., ARDIZZONE F., PEPE A., CARDINALI M., ZENI G., REICHENBACH P., LANARI R., (2009) "Analysis of ground deformation detected using the SBAS-DInSAR technique in Umbria, central Italy". Pure Appl. Geophys. 2009, $166,1425-1459$.

HARBAUGH A.W. (2005) - "MODFLOW-2005, The U.S. Geological Survey Modular Ground-Water Model-the Ground-Water Flow Process". U.S. Geological Survey Techniques and Methods 6-A16, 253 pp.

HARBAUGH A.W., BANTA E.R., HILL M.C., Mc DONALD M.G. (2000) - "Modflow-2000, the U.S. Geological Survey modular groundwater model. User guide to modularization concepts and the groundwater flow processes". U.S. Geological Survey Open File Report 00-92, $121 \mathrm{pp}$

KALF F.R. P., WOOLLEY D.R. (2005) - "Applicability and methodology of determining sustainable yield in ground water system". Hydrogeology Journal, 13(1) March, 295-312 pp.

LEE C.H. (1915) - "The determination of safe yield of underground reservoirs of the closed basin type". Trans. Amer. Soc. Civil. Engrs., vol. $78,148-151$ 
LLAMAS R. (2004) - "Water and Ethics. Use of groundwater". UNESCO International Hydrological Programme, World Commission on the Ethics of Scientific Knowledge and Technology, 33 pp

MARCHETTI G., MARTINELLI A. (1991) - "Gli acquiferi alluvionali dell'Umbria." (The alluvial acquifer of Umbria), In AA.VV., Le acque sotterranee in Umbria, a cura di S. Giaquinto, G. Marchetti, A. Martinelli, E. Martini, Protagon -GNDCI-CNR (pubbl. 413), Perugia, $13-48$ pp.

MARCHETTI G., MARTINI E. (1990) - "Carta di vulnerabilità degli acquiferi all'inquinamento della Valle Umbra Nord" (Vulnerability map of contamination of the Valle Umbra North aquifer). GNDCI-CNR (pubbl. n. 256), Perugia

MARCHETTI G., MARTINI A. (1991) - "Carta di vulnerabilità degli acquiferi all inquinamento della Valle Umbra Sud" (Vulnerability map of contamination of the Valle Umbra South aquifer). GNDCI-CNR (pubbl. n. 468), Perugia

McDONALD M.G, HARBAUGH A.W. (1988) - "A modular three-dimensional finite difference groundwater flow model". USGS TWRI 6-A1, 588 pp.

PREZIOTTI A. (1908) - "Le acque sotterranee della parte nordica della valle Folignate in rapporto all'irrigazione" (The groundwater in the northern part fo Foligno valley in relation to irrigation). Giornale di Geologia Pratica, Anno VII, Fascicolo III-IV, 68 pp., Perugia.

REGIONE UMBRIA - Servizio Geologico e Sismico Regionale (2007) "Carta Idrogeologica della Valle Umbra" (Hydrogeological map of the Valle Umbra).

REGIONE UMBRIA (2009) - "Piano di tutela della acque" (Water Protection Plan) - Approvato con D.G.R. n. 1570 del 1/12/2009. Entrata in vigore 31/12/2009 e modifiche 22/09/2011.
RIZA-RIVM (1991) - "Sustainable Use of Groundwater". National Institute of Public Health and Environmental Protection-Institute for Inland Water Management and Waste Water Treatment, $80 \mathrm{pp}$. Brouwer Offset B.V., Utrecht

RPA-Risorse Ambientali (1984) - "Studio geofisico complementare nella zona di Cannara. Perugia". (Geophysical complementary study in the Cannara zone. Perugia) Consorzio Acquedotti di Perugia. Rapporto Interno

SOPHOCLEOUS M.A. (2000) - "From safe yield to sustainable development of water resources-The Kansas experience". Journal of Hydrology, v. 235, 27-43 pp.

U.S. ENVIRONMENTAL PROTECTION AGENCY (1991) - "Wellhead Protection Strategies For Confined-Aquifer Settings". Office of Water, EPA 570/9-91-008, 183 pp., June, Washington D.C.

U.S. GELOGICAL SURVEY (2007) - "Water Budgets: Foundations for Effective Water-Resources and Environmental Management". U.S. Department of the Interior, U.S. Geological Survey, Circular 1308, 91 pp., Reston, Virginia

U.S. GEOLOGICAL SURVEY (1999) - "Sustainability of GroundWater Resources” U.S. Geological Survey Circular 1186, 79 pp., Denver, Colorado

U.S. GEOLOGICAL SURVEY (2007) - "Water Budgets: Foundations for Effective Water-Resources and Environmental Management". U.S. Geological Survey Circular 1308, 92 pp., Reston, Virginia

ZHENG C. (1988) - "PATH3D A Groundwater Path and Travel Time Simulator. User's Manual”. S.S. Papadopulos and Associates, $81 \mathrm{pp}$. Inc., Rockville, MD 